\title{
Mitigating Potentials of Antioxidant-Rich Plants in Earthworms Exposed to Glyphosate
}

Isaac 0 Ayanda ( $\square$ adebanjiolushola@rocketmail.com)

Covenant University

Tolulope 0. Ajayi

Covenant University

\section{Research Article}

Keywords: Catalase, Superoxide dismutase, Glutathione, Lipid Peroxidation, Glyphosate, Earthworm

Posted Date: March 19th, 2021

DOl: https://doi.org/10.21203/rs.3.rs-293784/v1

License: (c) (i) This work is licensed under a Creative Commons Attribution 4.0 International License. Read Full License 


\section{Abstract}

Glyphosate is a non-selective herbicide that has adverse effects on non-target organisms. This present study investigated the toxic effects of glyphosate on earthworms and the potential of antioxidant-rich plants, Ocimum gratissimum and Telfairia occidentalis remediate these effects. Earthworms (Eisenia fetida) were placed into four groups and treated with concentrations of 1,2 and $3 \%$ glyphosate in soil. The last group was a control group. The worms were collected on the 3rd, 7th and 14th, days postexposure. During these intervals, the weight of the worms and activities of antioxidant enzyme superoxide dismutase (SOD), catalase (CAT), glutathione (GSH), malondialdehyde (MDA) were measured to determine the level of antioxidant responses. Furthermore, the percentage of DNA fragmentation was measured to assess the level of DNA damage. Compared with the control group, earthworms exposed to glyphosate and fed with Ocimum gratissimum and Telfairia occidentalis showed varying responses, with increased activities of CAT, SOD, GSH and reduced levels of MDA. Also, decreased fragmented DNA was observed in earthworm groups fed with Ocimum gratissimum and Telfairia occidentalis in comparison with the group treated exclusively with the herbicide. These results suggest that toxicity from glyphosate exposure significantly reduced oxidative damage, lipid peroxidation and DNA damage in Eisenia fetida by the antioxidant-rich plants. It is conceivable that soil organisms could suffer a significant mortality when exposed to high concentrations of glyphosate. The cultivation of these plants should be encouraged while caution should be exercised in the use of the herbicides.

\section{Introduction}

Eisenia fetida is an important worm in scientific and agricultural processes. Its physiological features and environmental importance have been extensively reported in literature (Domínguez et al. 2010; Georgescu et al. 2011; Dedeke et al. 2016; Owagboriaye et al. 2016). Eisenia fetida is an earthworm specie with rapid growth (Pelosi et al. 2009), fast reproductive rates (Ansari and Saywack 2011), and it is potentially utilized for management of waste-products rich in microbial biomass (Domínguez et al. 2010). Furthermore, Eisenia fetida has a beneficial impact on many habitats, such as soil formation, soil structure, moisture regulation, nutrient cycling, cultural processes, climate regulation, pollution mitigation, and primary production (Blouina et al. 2013). The use of Eisenia fetida as sentinel organisms in environmental science, in comparison to other earthworm species, is due to the adaptability and strength of Eisenia fetida to a wide variety of environmental conditions, thus making it an ideal choice for laboratory-scale experiments.

Glyphosate, or N-(phosphonomethyl) glycine is a broad spectrum herbicide, used to destroy both broadleaf plants and grasses. Glyphosate was first recorded by Monsanto (Roundup) (Athanasios 2018). The herbicide blocks the production of proteins and compounds required for plants defense (Krüger et al. 2013). The efficacy of glyphosate is dependent on the disruption of the shikimic acid mechanism of enolpyruvylshikimate phosphate synthase (EPSPS). In Nigeria and other countries, it is a famously used as a weed-killer (Best-Ordinioha et al. 2017). 
The possible secondary target impacts of glyphosate on terrestrial species, is of great interest among researchers (Mijangos et al. 2009). Glyphosate has been discovered to have significant effects on earthworms (Marleena et al. 2019), it has been reported to hinder the enzymatic activities in earthworms (Gaupp-Berghausen et al. 2015). According to Correia and Moreira (2010), growth of the earthworms decreased significantly on exposure to glyphosate. Also, biological features of earthworms, such as behavior, growth and reproduction were also negatively impacted due to glyphosate exposure ( $\mathrm{Li}$ et al. 2010).

Hydroxyl species, superoxide species, and unsaturated oxygen species are the extremely reactive free radicals continually formed within stable living cells. They are collective referred to a reactive oxygen species (ROS). Reactive oxygen species (ROS), can alter detoxification enzyme activity leading to lipid peroxidation in cellular membranes or generating DNA damage (Lin et al. 2012; Zhu et al. 2011).

Cells generate antioxidant management techniques to prevent uncontrolled proliferation of these free radicals, which regulate the many required and beneficial free radicals present (Olorunfemi et al. 2014). Antioxidants can be found in all biotic cells, preventing damage from reactive oxygen species (ROS). The antioxidant system represses and controls the production of excessive free radicals when operating correctly, allowing the regulation of the metabolism of oxidative energy. Oxidative stress occurs when the cells of living organisms are unable to effectively and combat or manage unbalanced reactive oxygen species (Tan et al. 2018). Many biological catalysts, like catalase, and glutathione processes, are present in living system needed to ensure life. They tend to regulate and facilitate the proliferation, of oxidative stress, and subsequently the radicals responsible for the disorder in the tissues of organisms (Manoj et al. 2009).

Rich sources of antioxidants are mainly fruits and vegetables. In this study, we tested the mitigating potentials of two antioxidant-rich plants, Ocimum gratissimum (Scent leave) and Telfairia occidentalis (Ugu) on the earthworm (Eisenia fetida) exposed to varying concentrations of glyphosate.

\section{Materials And Methods}

\section{Collection and Maintenance of Earthworms:}

Earthworms were collected and carefully carried within an hour of collection to the laboratory in a moist soil sample. They were placed in plastic-pots (diameter: $25 \mathrm{~cm}$, length: $30 \mathrm{~cm}$ ) punctured at the bottom and perimeter (for easy drainage and aeration) and packed with soil acquired from a fertile field with no history of herbicide use was utilized for this experiment. At the initial stage during acclimatization, the earthworms were fed crushed egg shells, and the soil was watered every 48 hours to field capacity; $100 \mathrm{ml}$ of water per pot, to avoid excessive moisture content and water logging and this was continued during the course of the experiment. After 48 hours, the worms were extracted from the pots and kept on a moist filter-paper to rid the earthworms of their intestinal contents. 


\section{Experimental Design:}

The experiment was designed in line with studies conducted by Gaupp-Berghausen et al. (2015) with slight changes. A total of 120 earthworms were used for this experiment. The number of earthworms introduced per pots was according to the description of Edwards and Bohlen (1996) which suggested that an average of $>300$ worms occupy a square meter of soil. The earthworms were divided into 10 groups, ten earthworms per pot, three replicates and thirty earthworms per group. The antioxidant-rich plants were made available as detritus in a combination of broken egg shells and the earthworms were fed every 48hours, by mixing the feed combination with the soil. The earthworms were acclimatised for 14 days in the laboratory at room temperature $\left(23 \pm 1^{\circ} \mathrm{C}\right)$ as described by Heimbach (1984). After acclimatization, three concentrations of glyphosate $-1,2$ and 3 percent of glyphosate, which contained glyphosate concentration of $360 \mathrm{~g} / \mathrm{L}$ (Hebel Enge Biotech Co. Ltd) was applied twice. The worms were divided into four groups with varying concentrations per group, Group A: Control, only food and water; Group B: $1 \%$ glyphosate + Ocimum gratissimum (Scent Leaf); Group C: $2 \%$ glyphosate + Telfairia occidentalis (Ugu Leaf) and Group D: 3\% glyphosate and food alone. The experiment lasted 14 days.

\section{Determination of Worm Weight}

To determine their average weight, the earthworms were weighed together on a weighing scale. The average weights of the worms were taken and recorded at the start of the experiment. The weights were further taken on days 3,7 and 14. They were subsequently washed with distilled water, desiccated with moist filter-paper and after weighing, introduced into each bucket. Upon release, the earthworms burrowed directly into the soil.

\section{Oxidative Stress Assays}

The earthworms were collected from each pot on days 3, 7 and 14 respectively after exposure. Afterwards, they were properly washed with distilled water and saline to eliminate residual soil contents. 0.2 grams of the earthworm tissue was cut and subsequently homogenized in a solution of $1.8 \mathrm{ml}$ homogenizing buffer ( $50 \mathrm{mM}$ Tris- $\mathrm{Hcl}, 1.15 \% \mathrm{KCl}, \mathrm{pH} 7.4)$ for the antioxidant enzyme analysis.

\section{Lipid Peroxidation Analysis}

Lipid peroxidation of the earthworm body was determined using the method of Gagne (2014). Lipid peroxidation in the formation of thio-barbituric reactive substances (TBARS) was calculated by combining $1000 \mu \mathrm{l} \mathrm{TCA}(20 \%)$ and $2000 \mu \mathrm{l} \mathrm{TBA}(0.675 \%)$ with $0.5 \mathrm{ml}$ tissue supernatant and then heated at $100^{\circ} \mathrm{C}$ for 1 hour. After cooling, the precipitate was extracted for 5 minutes by centrifugation at $3500 \mathrm{X}$ $\mathrm{g}$ and the absorbance was measured at $535 \mathrm{~nm}$. The unit / $\mathrm{mg}$ protein lipid peroxidation was measured with a coefficient of molar-extinction of $1.54 \times 10^{5} \mathrm{M} / \mathrm{cm}$. 


\section{Analysis of Catalase Activity}

Catalase (CAT) activity was analyzed in the earthworms using the Beers and Sizer (1952) technique with a slight modification. The reaction mixture was prepared into quartz spectrophotometer cuvette. $\mathrm{H}_{2} \mathrm{O}_{2}$ was prepared with $\mathrm{PO}_{4}$ buffer; $100 \mu \mathrm{l}$ of tissue homogenate was added to $1.9 \mathrm{ml}$ of $30 \mathrm{mM}$ of $\mathrm{H}_{2} \mathrm{O}_{2}$ substrate. The absorbance of the sample was read at time zero $\left(A_{0}\right)$ and after 1 minute $\left(A_{1}\right)$ at $240 \mathrm{~nm}$.

\section{Analysis of Superoxide-dismutase (SOD) Activity}

The analysis of Superoxide dismutase (SOD) in earthworms was done following the method of Valeska et al. (2009). The function of superoxide-dismutase was analyzed by its potential in the inhibition of epinephrine auto-oxygenation. $2.95 \mathrm{ml}$ of $0.05 \mathrm{M} \mathrm{Na}_{2} \mathrm{CO}_{3}$ buffer $\mathrm{pH} 10.2,0.02 \mathrm{ml}$ of tissue supernatant and $0.03 \mathrm{ml}$ of epinephrine in $0.0025 \mathrm{~N} \mathrm{HCl}$ were used in the reaction mixture $(3 \mathrm{ml})$ to start the reaction. The reference cuvette had a buffer of $2.95 \mathrm{ml}$, a substrate of $0.03 \mathrm{ml}$ (epinephrine) and $0.02 \mathrm{ml}$ of $\mathrm{H}_{2} \mathrm{O}$. By measuring the absorbance shift at $480 \mathrm{~nm}$ for 60 seconds, enzyme activity was calculated.

\section{Analysis of Glutathione (GSH) Concentration}

GSH analysis was conducted in according to the method of Blume et al. (1975). In a test tube, $500 \mu \mathrm{L}$ of homogenized tissue was pipetted into $4000 \mu \mathrm{L}$ of $0.08 \mathrm{~N}$ sulphuric acid $\left(\mathrm{H}_{2} \mathrm{SO}_{4}\right)$ and carefully mixed and left for 10 mins at room temperature. $500 \mu \mathrm{L}$ of tungstate mixture was then pipetted to the precipitated protein. The bottle was covered and the solution was agitated thoroughly for 300 seconds. The mixture was kept for 120 seconds at $20-22^{\circ} \mathrm{C}$. Then, the solution was centrifuged at $860 \mathrm{rpm}$ for 20 minutes. In $2500 \mu \mathrm{L}$ of tris-buffer, two millilitres of the clear extract were pipetted, then $200 \mu \mathrm{L}$ of DNTB reagent was applied. By using $2000 \mu \mathrm{L}$ of water instead of homogenized tissue, a reagent blank was also prepared. The colour was produced after 30-60 seconds and the optical-density was calculated at $412 \mathrm{~nm}$.

\section{DNA Fragmentation Assay}

DNA fragmentation analysis was carried out according to Ibrahim et al. (2013). The earthworms were collected per pot on days 3, 7 and 14 after exposure. Afterwards, they were properly rinsed with distilled water and saline to remove residual soil contents and weighed. 100 milligrams of the earthworm tissue was cut, and subsequently digested in a solution of $1000 \mu \mathrm{L}$ buffer $(10 \mathrm{mM}$ Tris- $\mathrm{HCl}, \mathrm{pH} 7.4,10 \mathrm{mM}$ EDTA, and $0.5 \%$ Triton $\times 100$ ). Then the solution containing the earthworm tissues were incubated in an ecotherm at $56^{\circ} \mathrm{C}$ for 12 to $18 \mathrm{hr}$ in tightly capped tubes. After which, the remaining unused tissues were stored in a saline solution and refrigerated to preserve the harvested earthworm tissue for further analysis. 
Tissues are lysed in $1000 \mu \mathrm{L}$ buffer (10 mM Tris-HCl, pH 7.4, $10 \mathrm{mM}$ EDTA, and 0.5\% Triton $\times 100) .500$ $\mu \mathrm{L}$ of 25 percent TCA was pipetted separately into tubes containing the complete DNA pellets (marked $\mathrm{P}$ ) and the smaller particles of DNA supernatants (marked S). Both tubes are allowed to sit overnight at $4^{\circ} \mathrm{C}$, and precipitated DNA is acquired through centrifugation. Each tube is further treated with $80 \mu \mathrm{L}$ of $5 \%$ TCA, afterwards a heat treatment at $90^{\circ} \mathrm{C}$ for $15 \mathrm{~min}$ is implemented. $1000 \mu \mathrm{L}$ newly prepared diphenylamine (DPA) reagent is treated differently into each sample, tubes and are allowed to stay overnight at $20-22^{\circ} \mathrm{C}$, and optical density is set at $600 \mathrm{~nm}$. DNA fragmentation was calculated as follows:

$\%$ DNA fragmentation $=[S /(S+P)] * 100$ where $S$ is Supernatant and $P$ is Pellet. The intensity of extracted DNA was also calculated using Image $\mathrm{J}$ software.

\section{Statistical Analysis}

Statistical analysis was conducted using GraphPad Prism version (8.0.2) for windows. Mean values of the parameters were compared between the exposed earthworm groups and the control group using Oneway ANOVA. P-value less than (<) 0.05 was considered to be statistically significant.

\section{Results}

\section{Effect of Herbicide on Weight of Earthworms}

The average weight of earthworms in response to glyphosate exposure are as presented in Table 1. On day 0 , there was no significant difference $(P>0.05)$ in weight in groups A-D. Groups B and C showed a significant difference $(P<0.05)$ in weight on days 3 and 7 in comparison with the control. Furthermore, group $D$ showed a significant difference $(P<0.05)$ in weight on days 7 and 14 in comparison with the control. There was no significant difference $(P>0.05)$ between groups $A, B$ and $C$ on day 14 . 
Table 1

Average Weight (grams) of earthworms on exposed and unexposed of before and after 3,7 , and 14 days.

Treatments

Days

\begin{tabular}{|c|c|c|c|c|}
\hline & 0 & 3 & 7 & 14 \\
\hline Control (A) & $\begin{array}{l}10.94 \pm \\
0.20^{\mathrm{a}}\end{array}$ & $\begin{array}{l}9.84 \pm \\
0.19^{\mathrm{a}}\end{array}$ & $\begin{array}{l}10.94 \pm \\
0.19^{\mathrm{a}}\end{array}$ & $\begin{array}{l}10.44 \pm \\
0.19^{\mathrm{a}}\end{array}$ \\
\hline $\begin{array}{l}\text { Ocimum gratissimum }+1 \% \text { Herbicide } \\
\text { (B) }\end{array}$ & $\begin{array}{l}10.02 \pm \\
0.24^{\mathrm{a}}\end{array}$ & $\begin{array}{l}8.14 \pm \\
0.34^{b}\end{array}$ & $9.34 \pm 0.37^{b}$ & $\begin{array}{l}10.65 \pm \\
0.32^{\mathrm{a}}\end{array}$ \\
\hline $\begin{array}{l}\text { Telfairia occidentalis }+2 \% \text { Herbicide } \\
\text { (C) }\end{array}$ & $9.89 \pm 0.29^{a}$ & $\begin{array}{l}7.79 \pm \\
0.28^{b}\end{array}$ & $8.99 \pm 0.28^{b}$ & $\begin{array}{l}10.30 \pm \\
0.30^{\mathrm{a}}\end{array}$ \\
\hline $3 \%$ Herbicide alone (D) & $9.89 \pm 0.63^{a}$ & $\begin{array}{l}8.79 \pm \\
0.63^{\mathrm{a}}\end{array}$ & $7.59 \pm 0.60^{b}$ & $\begin{array}{l}6.290 \pm \\
0.61^{\mathrm{b}}\end{array}$ \\
\hline
\end{tabular}

Values with the same letters show no significant difference $(P>0.05)$.

\section{Effects of Herbicides on antioxidant enzymes}

\section{Catalase}

The activity of catalase in the earthworms are presented in Table 2. The group exposed to herbicide and Telfairia occidentalis showed a significant difference $(P<0.05)$ in catalase activity on day 3 in comparison with the control. Furthermore, only the group exposed exclusively to herbicide showed a significant difference $(P<0.05)$ in the activities of the enzyme on days 3,7 and 14 in comparison with the control and other groups. There was no significant difference $(P>0.05)$ between groups $A$ and $B$ throughout the treatment period.

Table 2

Activity of Catalase ( $\mu \mathrm{mol} / \mathrm{g}$ tissue) in the earthworms across the four treatment groups.

\begin{tabular}{|c|c|c|c|}
\hline Treatments & Days & & \\
\hline & 3 & 7 & 14 \\
\hline Control (A) & $0.124 \pm 0.01^{a}$ & $0.210 \pm 0.02^{\mathrm{a}}$ & $0.137 \pm 0.01^{a}$ \\
\hline Ocimum gratissimum $+1 \%$ Herbicide (B) & $0.125 \pm 0.01^{\mathrm{a}}$ & $0.182 \pm 0.02^{\mathrm{a}}$ & $0.126 \pm 0.01^{\mathrm{a}}$ \\
\hline Telfairia occidentalis $+2 \%$ Herbicide (C) & $0.028 \pm 0.02^{b}$ & $0.235 \pm 0.04^{a}$ & $0.144 \pm 0.01^{\mathrm{a}}$ \\
\hline 3\% Herbicide alone (D) & $0.021 \pm 0.01^{b}$ & $0.018 \pm 0.02^{b}$ & $0.010 \pm 0.03^{b}$ \\
\hline
\end{tabular}




\section{Superoxide dismutase}

The activity of superoxide dismutase in the earthworms are presented in Table 3 . All the treatment groups showed a significant difference $(P<0.05)$ in SOD activity on all the days in comparison with the control. However, there was no difference in SOD activity among the three treatment groups throughout the exposure period.

Table 3

Activity of superoxide dismutase (U/mg Protein) in the earthworms across the four treatment groups.

\begin{tabular}{|llll|}
\hline Treatments & Days & \\
\hline & 3 & 7 & 14 \\
\hline Control (A) & $320.5 \pm 52.28^{\mathrm{a}}$ & $328.2 \pm 59.80^{\mathrm{a}}$ & $325.2 \pm 61.20^{\mathrm{a}}$ \\
\hline Ocimum gratissimum + 1\% Herbicide (B) & $512.3 \pm 156.4^{\mathrm{b}}$ & $568.4 \pm 65.49^{\mathrm{b}}$ & $592.6 \pm 69.50^{\mathrm{b}}$ \\
\hline Telfairia occidentalis + 2\% Herbicide (C) & $540.7 \pm 81.67^{\mathrm{b}}$ & $586.1 \pm 117.60^{\mathrm{b}}$ & $564.5 \pm 74.20^{\mathrm{b}}$ \\
\hline 3\% Herbicide alone (D) & $425.0 \pm 28.42^{\mathrm{b}}$ & $473.1 \pm 88.53^{\mathrm{b}}$ & $630.5 \pm 231.4^{\mathrm{b}}$ \\
\hline Values with the same letters show no significant difference $(P>0.05)$. & \\
\hline
\end{tabular}

\section{Glutathione}

The concentration of glutathione in the earthworms are presented in Table 4. All the treatment groups showed no significant difference $(P>0.05)$ in glutathione concentration on day 3 in comparison with the control. However, only the group exposed exclusively to herbicide showed a significant difference $(\mathrm{P}<$ 0.05 ) in concentration of GSH on days 7 and 14 in comparison with the control and other groups. There was no significant difference $(P>0.05)$ between groups $A, B$ and $C$ throughout the treatment period. 
Table 4

Concentration of glutathione (GSH) $\mathrm{U} / \mathrm{g}$ tissue in the earthworms across the four treatment groups.

\begin{tabular}{|llll|}
\hline Treatments & Days & & \\
\hline & $\mathbf{3}$ & $\mathbf{7}$ & 14 \\
\hline Control (A) & $0.013 \pm 0.002^{\mathrm{a}}$ & $0.017 \pm 0.001^{\mathrm{a}}$ & $0.017 \pm 0.001^{\mathrm{a}}$ \\
\hline Ocimum gratissimum + 1\% Herbicide (B) & $0.015 \pm 0.001^{\mathrm{a}}$ & $0.019 \pm 0.001^{\mathrm{a}}$ & $0.021 \pm 0.002^{\mathrm{a}}$ \\
\hline Telfairia occidentalis + 2\% Herbicide (C) & $0.017 \pm 0.002^{\mathrm{a}}$ & $0.020 \pm 0.001^{\mathrm{a}}$ & $0.023 \pm 0.002^{\mathrm{a}}$ \\
\hline 3\% Herbicide alone (D) & $0.025 \pm 0.002^{\mathrm{b}}$ & $0.034 \pm 0.001^{\mathrm{b}}$ & $0.035 \pm 0.001^{\mathrm{b}}$ \\
\hline Values with the same letters show no significant difference $(\mathrm{P}>0.05)$. & \\
\hline
\end{tabular}

\section{Lipid Peroxidation (MDA)}

The levels of lipid peroxidation in the earthworms are presented in Table 5. The groups exposed to herbicide and Ocimum gratissimum as well as herbicide and Telfairia occidentalis showed a significant difference $(P<0.05)$ in levels of MDA in comparison with the control on day 7 . Furthermore, the group exposed exclusively to herbicide showed a significant difference $(P<0.05)$ in the levels of MDA on days 3 , 7 and 14 in comparison with the control. There was no significant difference $(P>0.05)$ between groups $A$, $B$ and $C$ on days 3 and 14 of the treatment period.

Table 5

Levels of lipid peroxidation (nMol/g Tissue) in the earthworms across the four treatment groups.

\begin{tabular}{|llll|}
\hline Treatments & Days & & \\
\hline & 3 & 7 & 14 \\
\hline Control (A) & $5.068 \pm 0.801^{\mathrm{a}}$ & $5.575 \pm 0.972^{\mathrm{a}}$ & $5.013 \pm 0.282^{\mathrm{a}}$ \\
\hline Ocimum gratissimum + 1\% Herbicide (B) & $6.169 \pm 1.154^{\mathrm{a}}$ & $6.857 \pm 0.411^{\mathrm{b}}$ & $6.370 \pm 0.446^{\mathrm{a}}$ \\
\hline Telfairia occidentalis + 2\% Herbicide (C) & $6.247 \pm 0.789^{\mathrm{a}}$ & $6.859 \pm 0.664^{\mathrm{b}}$ & $6.239 \pm 0.622^{\mathrm{a}}$ \\
\hline 3\% Herbicide alone (D) & $8.961 \pm 1.113^{\mathrm{b}}$ & $7.230 \pm 0.602^{\mathrm{b}}$ & $8.590 \pm 1.121^{\mathrm{b}}$ \\
\hline Values with the same letters show no significant difference $(P>0.05)$. & \\
\hline
\end{tabular}

\section{Percent of DNA Fragmentation}


The percent of DNA fragmentation in the earthworms are presented in Fig. 1. The group exposed to herbicide and Telfairia occidentalis showed a significant difference $(P<0.05)$ in the \% DNA fragmentation on day 3 in comparison with the control. Furthermore, only the group exposed exclusively to herbicide showed a significant difference $(P<0.05)$ in the \% DNA fragmentation on days 3,7 and 14 in comparison with control and other groups. There was no significant difference $(P>0.05)$ between groups $A$ and $B$ throughout the treatment period. The intensity of DNA as calculated using Image $\mathrm{J}$ software is as presented in Table 6.

Table 6

\begin{tabular}{|c|c|c|c|}
\hline \multirow[t]{2}{*}{ Treatments } & \multicolumn{3}{|l|}{ Days } \\
\hline & 3 & 7 & 14 \\
\hline Control (A) & $\begin{array}{l}4370.63 \pm \\
58.34^{\mathrm{a}}\end{array}$ & $\begin{array}{l}29596.52 \pm \\
1150.14^{\mathrm{a}}\end{array}$ & $\begin{array}{l}29555.48 \pm \\
640.52^{a}\end{array}$ \\
\hline $\begin{array}{l}\text { Ocimum gratissimum }+1 \% \text { Herbicide } \\
\text { (B) }\end{array}$ & $\begin{array}{l}2367.27 \pm \\
540.27^{b}\end{array}$ & $9877.97 \pm 187.63^{b}$ & $\begin{array}{l}16444.1 \pm \\
621.05^{b}\end{array}$ \\
\hline $\begin{array}{l}\text { Telfairia occidentalis }+2 \% \text { Herbicide } \\
\text { (C) }\end{array}$ & $\begin{array}{l}1876.24 \pm \\
144.83^{c}\end{array}$ & $\begin{array}{l}7903.764 \pm \\
214.75^{b}\end{array}$ & $\begin{array}{l}16216.57 \pm \\
329.53^{b}\end{array}$ \\
\hline $3 \%$ Herbicide alone (D) & $\begin{array}{l}2769.61 \pm \\
175.95^{b}\end{array}$ & $\begin{array}{l}18882.98 \pm \\
1681.53^{\mathrm{C}}\end{array}$ & $\begin{array}{l}25545.74 \pm \\
438.19^{c}\end{array}$ \\
\hline
\end{tabular}

\section{Discussion}

The weight of earthworms was a more susceptible cue in comparison to mortality when evaluating the toxicity of glyphosates on soil organisms (Shahla and Doris 2010). The results in Table 1 shows that on day 14 the groups fed with Ocimum gratissimum and Telfairia occidentalis had an increase in weight in comparison to the group fed exclusively with herbicide. Various research on the detrimental effects of glyphosate on earthworm development have previously been reported. Result from this study are in line with studies performed by Krishan and Pooja (2018), which found that earthworms exposed exclusively to glyphosate showed weight reduction. On the contrary, the experiment revealed that the groups fed with antioxidant-rich plants had an improvement in body weight, indicating that Ocimum gratissimum and Telfairia occidentalis had a beneficial effect on the body weight of earthworms.

Catalase (CAT) is a natural enzyme that is found every oxygen-exposed living organism. It is a very significant enzyme in the defense of the cell from ROS oxygenated damage. According to the results (Table 2), the activity of CAT increased in group B. The enhancement in CAT activity of Groups B and C can be attributed to an increase in the amount of the antioxidant-rich plants that occurred as an adaptive feature for sustaining the hydrogen peroxide level (Liu et al. 2011). 
SOD defends in resistant to superoxide radical $\left(\mathrm{O}_{2}{ }^{-}\right)$, which destroy cells and its biological complex. From Table 3, it was observed that the group B group had the highest activity of SOD, followed closely by the group $\mathrm{C}$ group, while the herbicide alone group recorded the least values of SOD activity among the three treatment groups when compared with the control throughout the experiment. These results were in accordance with studies carried out by Ighodaro and Akinloye (2018). In the group treated with herbicide alone, the decreased SOD activity is related to excessive generation of ROS resulting from glyphosate exposure at a concentration of $3 \%$. The presence of antioxidant-rich plants would have helped to reduce the inhibition of SOD activity. $\mathrm{H}_{2} \mathrm{O}_{2}$ is an important end-product of SOD reaction and is poisonous to cells (Ighodaro and Akinloye 2018).

Overall, the antioxidant enzymatic biomarkers, CAT and SOD, play essential roles in destroying oxygen and hydrogen peroxide species effectively. This current experiment, show the presence of the two biomarkers were elevated in the groups fed with the antioxidant rich plants under glyphosate influenced conditions after 14 days of exposure. The results can be broken into two cycles on the basis of the observed differences in the antioxidant enzyme activities. The first cycle of effects (group B and C), the stimulation or increased presence was recorded in the two biomarkers, which showed that SOD and CAT activities are positively influenced by both Ocimum gratissimum and Telfairia occidentalis and these enzymes showed a cooperative role to shield cellular lipids from oxidative stress due to glyphosate exposure. The second cycle of effects, showed that the activities of CAT in the group treated with herbicide alone reduced to concentrations much lower than that of the control group. This may be due to the fact that high glyphosate concentrations (3\%) have activated the antioxidant mechanism to scavenge oxidative species, or that the amount of reactive species released by glyphosate has obviously impaired the metabolism of the earthworm after 14 days of exposure. This phenomenon is in accordance with (Liu et al. 2011). In addition, SOD enzyme inhibition would result in a decrease in the activity of the CAT enzyme due to a decrease in the production of hydrogen peroxide from SOD activities (Liu et al. 2011). For the successful elimination of oxidative radicals from tissues, the equilibrium between these enzymes is essential (Ifemeje et al. 2015). Therefore, because of the aggregation of superoxide radicals and hydrogen peroxide, a reduction in the activity of these enzymes can lead to a variety of damaging impacts. The administration of antioxidant-rich plants results in the increase to near-normal values of these enzymes, thereby defending the tissues against oxidative damage.

Glutathione is an important non-proteinaceous thiol in biotic organisms and plays a key role in organizing the antioxidant protection mechanism of the earthworm (Aquilano et al. 2014). Glutathione anchors a vital role in the scavenging of cellular radical oxygenated species (such as $\mathrm{H}_{2} \mathrm{O}_{2}, \mathrm{O}_{2}$ and $\mathrm{OH}$ ) as part of the cellular first layer defence system that shields organisms from oxidative stress (Forman et al. 2009). According to Lu (2013), an increase is often indicative of initiation of cellular defense mechanism in response to increasing concentration of free radical in the cell while a decrease may indicate an overrun of the antioxidant defense. Earthworms treated with both Ocimum gratissimum and Telfairia occidentalis showed significant restoration of GSH content in their tissues. The elevated GSH content in the tissues indicates that the GSH-dependent detoxification of free radicals could be responsible for protecting 
membrane tissue. Administration of Ocimum gratissimum and Telfairia occidentalis increased the levels of GSH in glyphosate exposed earthworms. Both Ocimum gratissimum and Telfairia occidentalis possess antioxidant properties as reported extensively in literature (Okonkwo and Njoku 2011).

Lipid peroxidation is a process caused by free radicals that results in oxidative degradation of polyunsaturated fatty acids. Low lipid-peroxide amounts are found in earthworm tissues under physiological conditions (Owagboriaye et al. 2020). In previous research, lipid peroxidation has been utilized as a biomarker to observe the influence of toxins (HHCB and Triclosan) on earthworms (Lin et al. 2010; Liu et al. 2011). Glyphosate-induced cellular damage mechanisms have been documented to be related to the variability of the cell membrane due to lipid peroxidation (Chen et al. 2011). In the present study, a rise in the levels of lipid peroxidation in glyphosate-induced earthworm tissue was observed. The results agrees with studies carried out by Zhang et al. (2013) on the effects of fomesafen on earthworms. Additionally, the observed increase in the MDA levels can be due to the exposure of the earthworms exclusively to the herbicide, resulting in the formation of excessive ROS. Lipid peroxidation resulting from the lipid reaction of free radicals is considered an essential aspect of cell damage triggered by a free radical attack (Liu et al. 2010). Increased lipid peroxidation has long been known to induce functional degradation of different tissues (Ifemeje et al. 2015). Therefore, tissue destruction that leads to complications can be directly due to increased oxidative stress. Administration of Ocimum gratissimum and Telfairia occidentalis, in our study, significantly decreased the concentration of lipid peroxidation and hydro-peroxides in groups $\mathrm{B}$ and $\mathrm{C}$.

It is necessary to recognize any possible interactions between glyphosate and earthworm DNA in a sensitive way. Fragmentation of DNA is one of the hallmarks of apoptotic cell death (Kaczanowski et al. 2011). Particular significance has been acquired by the analysis of the genotoxic impacts of treated soil herbicides and their leachate, particularly in the case of constant exposure due to repetitive applications. Therefore, genotoxic effect will result in major disruptions in one or more generations attributable to glyphosate (Silvana et al. 2018). Some herbicides have also been shown to cause the development of reactive oxygen species (ROS) that could be involved in the creation of single-strand DNA breaks and chromatin cross-linking (Silvana et al. 2018; Kaczanowski et al. 2011). The elevated DNA fragmentation can be related to increased oxidative stress induced by glyphosate. This lipid peroxidation is ultimately responsible for the initiation of DNA fragmentation (Li et al. 2010). It can be observed from Fig. 1 that there was significant fragmented DNA in glyphosate-exposed worms in comparison with the control. Also, results observed from the Image $\mathrm{J}$ analysis showed that DNA intensity was higher in the control groups compared with the glyphosate-exposed groups all through the period of the experiment. DNA intensity in the group exposed to only the herbicide was higher on days 7 and 14 compared to day 3 . Also, the DNA intensity for this group was higher than in groups $B$ and $C$. It may mean that while the antioxidant-rich plants prevented too much DNA damage in the earthworms in groups $B$ and $C$, in group D, DNA repair occurred as the exposure progresses. According to Morales et al. (2016), cells have multiple DNA repair mechanisms that compete with one another for the repair strand breaks. 
In conclusion, this study showed that the antioxidant-rich plants, Ocimum gratissimum and Telfairia occidentalis were efficient in protecting earthworms against oxidative stress from glyphosate exposure while also alleviating weight loss which occurred as a result of the exposure of the earthworms to glyphosate. This was observed in the increased activities of catalase (CAT), glutathione (GSH) and superoxide dismutase (SOD) and lower levels of Lipid peroxidation (MDA) in the tissues of the glyphosate-exposed earthworms in comparison with the unexposed group.

\section{Declarations}

\section{Ethical Approval}

All of the experimental procedures and protocols employed in this study were ratified by the Health Ethics Research Committee of Covenant University.

\section{Consent to Participate:}

Not applicable

\section{Consent to Publish:}

Not applicable

\section{Availability of data and materials}

All data generated and analyzed in the course of the study are included in the manuscript

\section{Competing Interests}

The authors declare that they have no competing interests

\section{Funding}

This research did not receive any specific grant from funding agencies in the public, commercial, or notfor-profit sectors

\section{Authors' Contributions}


Isaac 0 . Ayanda conceived and designed the experiments, analyzed and interpreted the data; edited the manuscript. Tolulope 0 Ajayi contributed reagents and materials, conducted experiment and wrote the draft manuscript.

\section{Acknowledgment}

The authors would like to appreciate the technologists in the Departments of Biological Sciences and Biochemistry Covenant University, Ota for their assistance during the experiment

\section{References}

1. Ansari AA, Saywack P (2011). Identification and classification of earthworm species in Guyana. Intl J Zool Res 7:93-99.

2. Aquilano K, Baldelli S, Ciriolo MR (2014). Nuclear recruitment of neuronal nitric-oxide synthase by asyntrophin is crucial for the induction of mitochondrial biogenesis. J Biol Chem 289:365-378.

3. Athanasios V (2018). Glyphosate, the Most Widely Used Herbicide: Health and safety issues; why scientists differ in their evaluation of its adverse health effects. J Sci Rev 10:1-41.

4. Beers RF, Sizer IW (1952). A spectrophotometric method for measuring the breakdown of hydrogen peroxide by catalase. J Biol Chem 195:133-140.

5. Best-Ordinioha JC, Ataga EA, Ordinioha B (2017). The effect of the application of different rates of herbicides on the residual level of the herbicides and their metabolites in harvested maize cobs. Port Harcourt Med J 11:122-126.

6. Blouina M, Hodsonb ME, Delgadoc EA, Bakerd G, Brussaarde L, Buttf KR, Daig J, Dendoovenh L, Peresi G, Tondohj JE, Cluzeauk D, Brunl JJ (2013). A review of earthworm impact on soil function and ecosystem services. Euro J Soil Sci 64:161-182.

7. Blume KG, Paniker NA, Beutler E (1975). Glutathione. In L. Flohé, H. Benöhr, H. Sies, H.D. Waller \& A. Wendel (Eds.), (pp. 157-165). New York: Academic Press.

8. Chen YC, Lin JT, Liu SC, Lu PS, Yang DJ (2011). Composition of flavonoids and phenolic acids in lychee (Litchi chinensisSonn.) flower extracts and their antioxidant capacities estimated with human LDL, erythrocyte and blood models. J Food Sci 76:724-728.

9. Correia FV, Moreira JC (2010). Effects of glyphosate and 2, 4-D on earthworms (Eisenia fetida) in laboratory tests. Bull Environ Contam Toxicol 85:264-268.

10. Dedeke GA, Owagboriaye FO, Ademolu KO, Olujimi OO, Aladesida AA. (2018). Comparative assessment on mechanism underlying renal toxicity of commercial formulation of roundup herbicide and glyphosate alone in male albino rat. Intl J Toxicol 37:285-295.

11. Domínguez J, Aira M, Gómez-Brandón M (2010). Vermicomposting: earthworms enhance the work of microbes: In Microbes at work (pp. 93-114). Springer, Berlin, Heidelberg. 
12. Edwards CA, Bohlen PJ (1996). Biology and ecology of earthworms ( $3^{\text {rd }}$ ed.) London: Chapman and Hall, 426.

13. Forman HJ, Zhang H, Rinna A (2009). Glutathione: overview of its protective roles, measurement, and biosynthesis. Mol Aspects Med 30:1-12.

14. Gagne F. (2014). Biochemical Ecotoxicology: Principles and Methods, Oxidative stress ( $1^{\text {st }}$ ed.). New York: Academic Press, 110-111.

15. Gaupp-Berghausen M, Hofer M, Rewald B, Zaller JG (2015). Glyphosate-based herbicides reduce the activity and reproduction of earthworms and lead to increased soil nutrient concentrations. Sci Reports 5:1-9.

16. Georgescu B, Georgescu C, Daraban S (2011). Use of Lumbricides species as biological indicators of environmental pollution with metalodisrupters. Lucrari Ştiinţifice 55:63- 67.

17. Heimbach F. (1984). Correlation between three methods for determining the toxicity of chemicals to earthworms. Pest Sci. 15:605-611.

18. Ibrahim B, Sowemimo A, Spies L, Koekomoer T, Venter M, Odukoya O. (2013). Antiproliferative and apoptosis inducing activity of Markhamia tomentosa leaf extract on Hela cells. J Ethnopharmacol 149:45-49.

19. Ifemeje JC, Udedi SC, Okechukwu AU, Nwaka AC, Lukong CB, Anene IN, Egbuna C, Ezeude (2015). Determination of Total Protein, Superoxide Dismutase, Catalase Activity and Lipid Peroxidation in Soil Macro-fauna (Earthworm) from Onitsha Municipal Open Waste Dump. J Sci Res Reports 6:394403.

20. Ighodaro OM, Akinloye OA (2018). First line defence antioxidants-superoxide dismutase (SOD), catalase (CAT) and glutathione peroxidase (GPX): Their fundamental role in the entire antioxidant defence grid. Alexandria J Med 54:287-293.

21. Kaczanowski S, Sajid M, Reece SE. (2011). Evolution of apoptosis-like programmed cell death in unicellular protozoan parasites. Parasites Vectors 4:1-8.

22. Krishan K, Pooja K. (2018). A review on the effect of herbicides on the earthworms. Intl J Zool Stud 3:120-125.

23. Krüger M, Shehata AA, Schrodl W, Rodloff A. (2013). Glyphosate suppresses the antagonistic effect of Enterococcus spp on Clostridium botulinum. Anaerobe 20:74-80.

24. Li XY, Luo YR, Yun MX, Wang J, Wang JJ (2010). Effects of 1-Methyl-3 Octylimidazolium Bromide on the Anti-oxidant System of Earthworms. Chemosphere 78:853-858.

25. Lin DS, Zhou QX, Xie XJ, Liu Y (2010). Potential biochemical and genetic toxicity of triclosan as an emerging pollutant on earthworms (Eisenia fetida). Chemosphere 81:1328-1333.

26. Lin DS, Xie XJ, Zhou QX, Liu Y (2012). Biochemical and genotoxic effect of triclosan on earthworms (Eisenia fetida) using contact and soil tests. Environ Toxicol 27:385-392

27. Liu S, Zhou QX, Wang YY (2011). Ecotoxicological responses of the earthworm Eisenia fetida exposed to soil contaminated with HHCB. Chemosphere 83:1080-1086. 
28. Lu C, Kim J, Fuller MT (2013). The polyubiquitin gene Ubi-p63E is essential for male meiotic cell cycle progression and germ cell differentiation in Drosophila. Development 140:3522-3531.

29. Manoj NT, Unnikrishnan AS, Sundar D (2009). Tidal asymmetry in the Mandovi and Zuari estuaries, the west coast of India. J Coastal Res 10:1187-1197.

30. Marleena H, Juha M, Irma S, Kari S, Marjo H (2019). Effects of a glyphosate-based herbicide on soil animal trophic groups and associated ecosystem functioning in a northern agricultural field. Sci Reports 9:1-13.

31. Mijangos I, Becerril JM, Albizu I, Epelde L, Garbisu C. (2009). Effects of glyphosate on rhizosphere soil microbial communities under two different plant composition by cultivation dependent and Independent methodologies. Soil Biol Biochem 41:5-13.

32. Morales ME, Derbes RS, Ade CM, Ortego JC, Stark J, Deininger PL, et al. (2016) Heavy Metal Exposure Influences Double Strand Break DNA Repair Outcomes. PLoS ONE 11(3): e0151367. https://doi.org/10.1371/journal.pone.0151367

33. Okonkwo CJ, Njoku OU (2011). Antioxidant Effect of Ocimum gratissimum Linn. Leaf Extract Against Carbon Tetrachloride (CCl4)-Induced Oxidative Stress in Wistar Albino Rats. Intl J Curr Res 2:01-07.

34. Olorunfemi AE, Munavvar AS, Hassaan AR (2014). A Review of the Pharmacological and Biological Activities of the Aerial Parts of Telfairia occidentalis Hook. f. (Cucurbitaceae). Trop J Pharma Res 13:1761-1769.

35. Owagboriaye F, Dedeke G, Bamidele J, Aladesida A, Isibor P, Feyisola R, Adeleke, M (2020). Biochemical response and vermiremediation assessment of three earthworm species ( $\mathrm{Alma}$ millsoni, Eudrilus eugeniae and Libyodrilus violaceus) in soil contaminated with a glyphosate-based herbicide. Ecol. Indicat 108:1-13.

36. Owagboriaye FO, Dedeke GA, Ademolu KO (2016). Glutathione-S-transferase production in earthworm (Annelida: Eudrilidae) as a tool for heavy metal pollution assessment in abattoir. Rev De Biol Trop 64:779-789.

37. Pelosi C, Bertrand M, Roger-Estrade J (2009). Earthworm community in conventional, organic and direct seeding with living mulch cropping systems. Agron Sustain Dev 29:287-295. doi:10.1051/agro/2008069

38. Shahla Y, Doris, D. (2010). Effects of Pesticides on the Growth and Reproduction of Earthworm: A Review. Appl Environ Soil Sci 5:1-10. Silvana PC, María ES, José LA, Santiago M, Marcelo LL, Walter DM (2018). Genotoxic Evidences of Glyphosate and Chlorpyriphos on Eisenia fetida Coelomocytes. Adv. Environ Stud 2:82-90.

39. Tan BL, Norhaizan ME, Liew WP, Sulaiman RH (2018). Antioxidant and Oxidative Stress: A Mutual Interplay in Age-Related Diseases. Front Pharmacol 9:1162.

https://doi.org/10.3389/fphar.2018.01162

40. Valeska CJ, Eva K, Claudia W (2009). Bioaccumulation of glyphosate and its formulation Roundup Ultra in Lumbriculus variegatus and its effects on biotransformation and antioxidant enzymes. Environ Poll 157:57-63. 
41. Zhang Q, Zhu L, Wang J, Xie H, Wang J, Han Y, Yang J (2013). Oxidative stress and lipid peroxidation in the earthworm Eisenia fetida induced by low doses of fomesafen. Environ Sci Poll Res 20:201208.

42. Zhu LS, Dong XL, Xie H, Wang J, Wang JH, Su J, Yu CW (2011). DNA damage and effects on glutathione-S-transferase activity induced by atrazine exposure in zebrafish (Danio rerio). Environ Toxicol 26:480-488.

\section{Figures}

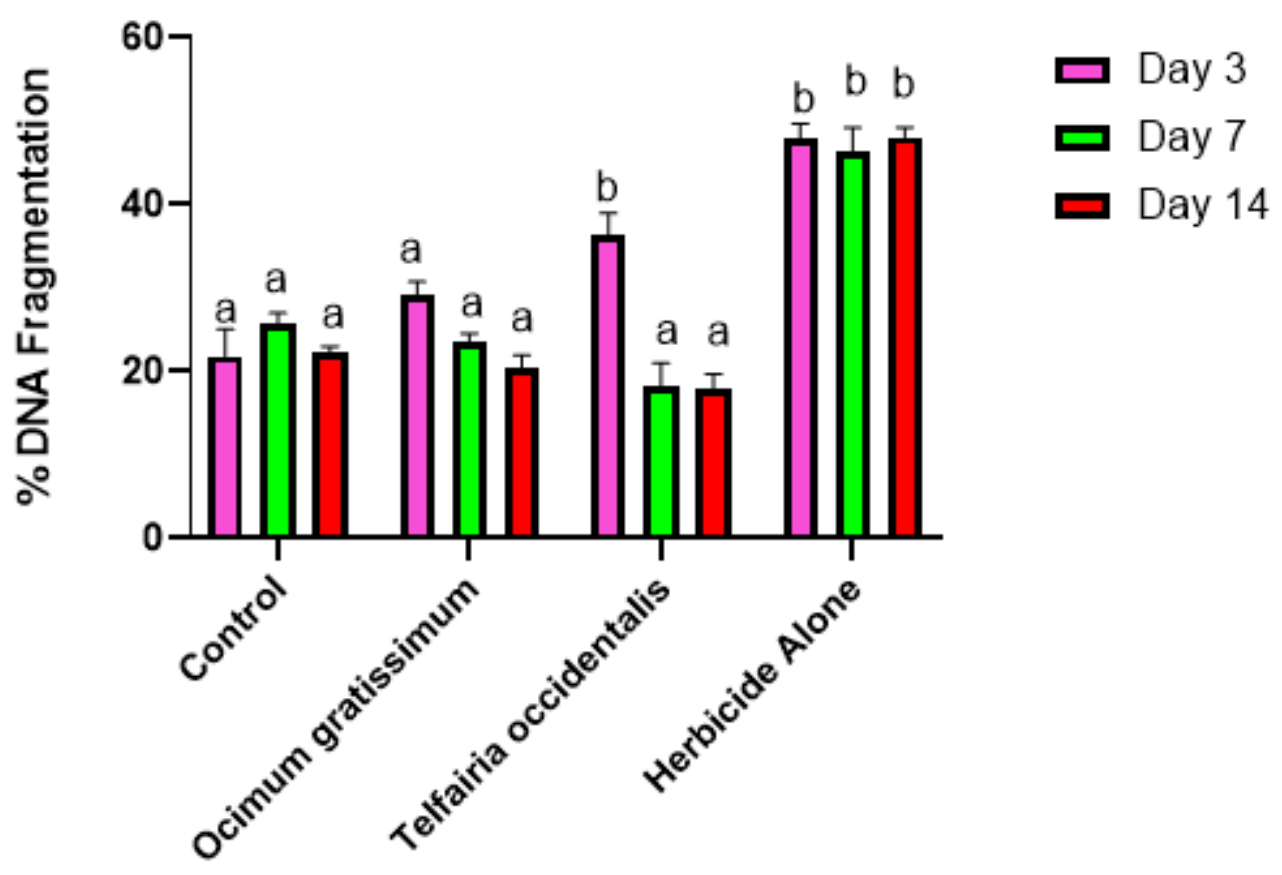

\section{Treatment Groups}

Figure 1

Percent of DNA fragmentation in earthworms across the treatment and control groups from day 3-14. 